\title{
STONE AGE MAN IN CEYLON
}

$P$ E. P. DERANIYAGALA has written an important paper entitled "The Stone Age and Cave Men of Ceylon (J. Roy. Asiatic Soc., Ceylon Branch, 34, 92 ; September 1940). Before 1936, the conclusions at which specialists had arrived relating to the prehistoric stone artefacts of Ceylon were extremely divergent owing to the absence of glacial deposits and of vertebrate fossils upon which these conclusions might be based. The second impediment no longer exists. Recent discoveries of an extinct hippopotamus, rhinoceros and race of elephant associated with stone artefacts may, it is argued, be assigned to the Upper Pleistocene, being younger than the Narbudda deposits of the Middle Pleistocene in which the hippopotamus occurs with three extinct proboscidian genera. The presence of the lion fossil and the absence of tiger and king cobra in Ceylon suggest that the island's extinct fauna entered before the last two descended far into peninsular India, while the absence of the horse indicates that the large extinct mammals entered Ceylon after the extinction, temporary or final, of this ungulate in India. If this be correct, these fossils of Ceylon must be regarded as comparatively recent; nor can the primitive stone artefacts be held to be the earliest handiwork of man, while the hitherto unexplored river terraces may reveal an earlier phase when stone cultures began in the island.

Man possibly entered Ceylon before developing the technique of making implements of stone, and acquired this art independently after the isolation of the island. Lacking the incentive of northern invasian which affected his continental relatives, he failed to advance beyond a phase akin to the Abbevellian, in which indeed he remained almost to the end of the early stone age culture of Ceylon in Pleistocene times or later. The poorly developed second phase of early stone age culture was replaced by the neolithic by a transition sufficiently abrupt to suggest that Ceylon's palæolithic man accompanied the hippopotamus and other large mammals into extinction, possibly as a result of an arid spell. The further possibility exists that when India and Ceylon were reconnected, the stone age races of India overran the island, and palæolichic man, if not already extinct, was unable to withstand their superior numbers and more efficient weapons.

The tendency of the Veddas to throw back to two physical types differing from other races in Ceylon, suggests that more than one neolithic race entered the island, a view supported by the occurrence in India of certain ancient pre-Dravidian races--Irula, Panyan, Kurumba, etc.

During Pleistocene times and later, Ceylon seems to have been united with India during both warm and cold spells. The final separation was still incomplete even so late as early historic times, as appears in the Ramayana. In addition, the topography of Ceylon fluctuated considerably, earth movements apparently bringing about a swift river phase, which was replaced by a phase of slow rivers and lakes, followed by further movement in which the lakes and many rivers disappeared, leaving only small streams or a series of swamps. The broad valley between the central mountain mass of Sri Padhé, or Adam's Peak, and the outlying range to its south- west is a source of fossils and artefacts, which also occur in the adjoining strike valleys. These comprise the Ratnapura series, which display much superficial laterization, possibly as a result of the south-west monsoon.

As the best evidence, both palæontological and archæological, is derived from the deposits of the strike valleys of this area, it is proposed to give to this stone age culture the name Ratnapura. It comprises two phases, of which the lower and earlier is extremely crude without any well-defined general shapes, has a crude flaking technique with scarcely any retouching, and contains a considerable proportion of pebble artefacts. The implements are about half the size of the quartzite palæoliths of Madras and show more affinity to the early Soan of Northern India. The materials employed are chert, quartz, corundum and jasper. The upper Ratnapura inplements are smaller than those of the lower culture, and show some attempt at retouching, scraper-like forms and the commencement of a crude handaxe; and also entire crystals of quartz or corundum, sometimes flaked to a sharp edge at the apex and roughly chipped, were employed. The upper phase did not develop far before it became ex. tinct.

The relative scarcity or absence of palæoliths from the highest of the peneplanes of Ceylon suggests that during palæolithic times this region was too cold for autochthonous tropical races, as it is partially to-day. Since neolithie implements abound here, it is possible that either one neolithic race was driven into the cold area by another, or that all the neolithic races were forced into it by the advent of metal-using man. Being thus thrown together, they interbred and degenerated into the so-called Veddas, who never manufactured metal implements and use shells for this purpose down to the present day. Neolithic man inhabited caves, and his implements appear to be mainly composite, that is, set in a wooden handle, as the stone artefacts are too small for use as single weapons. These stone artefacts usually occur at two levels, those of the lower being twice as large as those from the upper, which also possesses a greater number of types. The culture failed to develop so far as that of India, and the art of grinding and polishing was almost unknown. Generally, the implements are little worked if made of quartz; but occasional pigmy implements are as delicately finished as Solutrean. The name Balangoda is proposed for this culture, after the cave from which the implements are best known. The common type of pottery found in the deposits has a wicker or mat-basket design, but another form, probably prehistoric, has a wicker-loop design on the inner surface. Certain types of potsherd found in both neolithic and protohistoric appear to have survived with little variation down to modern times. Pieces of hæmatite show flat surfaces where they have been ground for pigment. Bone splinters ground to a point at one or both ends were possibly used as borers, needles, or for fishing.

The best prehistoric deposits occurred in caves notably difficult of access, but close to a stream which flowed down the rock near the entrance. Each cave possessed a sandy outer platform with a lookout rock, and lay under the shelter of a large over- 
hanging shelf of rock. Neolithic man generally piled his refuse not at the cave mouth but on one side of the platform.

A number of the caves have been investigated, and from the evidence of the deposits of which details are given, it is apparent that the neolithic colony inhabiting a rock shelter comprised several families, of which the men were hunters, trappers and fishers, while the women collected fruit, nuts and shell-fish. Some degree of agriculture may have been practised. Calcined bones furnish evidence of the use of fire and the practice of roasting game.

\section{PRODUCTION OF DRUGS WITHIN THE BRITISH EMPIRE}

$\mathrm{T}$ HE Appendix to the recently published War Memorandum by the Medical Research Council on "Economy in the Use of Drugs in War-Time" (H.M. Stationery Office. $3 d$. net) is of more durable interest than the body of the Memorandum, since it proposes a long-term plan for the cultivation of medicinal plants, whereas the special need for economy in the prescription of scarce drugs will pass with the emergency. The Appendix consists of two lists of drugs the cultivation of which in the British Empire should be encouraged. The first list relates to domestic production and the second to production in the Colonial Empire. It is not proposed to comment, in this note, on all the items named in the Appendix, but to make a few observations based upon the results of experimental work designed to ascertain whether it is feasible to cultivate economically and on a commercial scale, either at home or in some Empire country overseas, certain medicinal plants for the supply of which Great Britain has paid tribute in the past to foreign nations.

Taking first the list of drugs which the Memorandum recommends for production in the United Kingdom, it is proposed to refer to cascara sagrada, ergot, dill, gentian and lobelia. In the past the bulk of Great Britain's large imports of cascara sagrada has been supplied from forests on the American side of the north-west Pacific coast; contributions from the Canadian side have been comparatively small. Experiments have proved that the shrub from which the bark is peeled can be grown in certain soils in Great Britain as a coppice crop on a five-year rotation. An additional advantage of home cultivation is that the wood remaining after the bark has been peeled from it could be converted into charcoal equal in quality to that obtained from alder buckthorn for the manufacture of explosives.

Ergot, of which large quantities are consumed by the British drug manufacturing industry, is supplied mainly by Portugal and Spain. It could be produced in Great Britain, the most favourable places for this purpose being in the west of England and in Wales. Already plans have been laid for experiments, and research workers are devoting attention to the selection of the species and strain of the fungus. It is satisfactory to know that the danger of a serious infection of cereals other than rye is slight. The aim is to select strains of high alkaloidal content, and it may be observed that much of the information concerning the alkaloidal content dates back to the time before the discovery of the alkaloid ergometrine. Chemical methods of analysis for differentiating water-soluble alkaloid (ergometrine group) from water-insoluble alkaloid (ergotoxine group) have been devised, and it seems desirable that cultivation experiments should be controlled on this basis. Incidentally, publications from the Pharmacopœia laboratory have indicated the possibility that the official standards of the British Pharmacopœia will be eventually on this basis.

Dill, which was formerly supplied largely from Germany, can be grown as a cover crop with caraway, the dill being harvested in the first year and the caraway in the second; similarly, coriander, which is already cultivated in England, may be used as a cover crop for caraway. With regard to gentian, which in normal times was imported from Italy, Spain and France, there are definite grounds for stating that it could be grown in Great Britain, but several years are needed to develop the large roots which are preferred in the London drug market. Lobelia, the present source of supply of which is the United States, can be grown on moderate to light soils in the southern half of England.

Coming now to the list of some forty vegetable drugs and essential oil-yielding plants which the Memorandum recommends for cultivation in some parts of the British Empire overseas, it is satisfactory to know that the following are already in production in India : nux vomica, podophyllum resin, rhubarb, belladonna, digitalis, henbane, jalap, lobelia, opium, squill, senna, santonin, karaya gum, and the following oils : arachis, eucalyptus, hydnocarpus and castor. The cultivation in India of psyllium and agar could also be developed, and there seems but little reason to doubt that some of the soils and climates of India are suitable for the cultivation of some of the other substances in the list set out by the Medical Research Council.

Australia, too, and New Zealand are countries which can supply some of Britain's needs for drugs. Such substances as digitalis, ephedra, ergot, liquorice, peppermint and pyrethrum, should repay investigation by cultivation in suitable places in Australia. The leaves of a tree indigenous to Australia contain hyoscyamine and hyoscine, and should prove a valuable source of these alkaloids. New Zealand is already a potential source of digitalis ; it is produced there in commercial quantities. The species of fungus which grows on Festuca orgot in New Zealand is esteemed as a source of ergotamine. Many other drugs in the list could be grown economically in that Dominion. Canada has not been a fruitful source of vegetable materia medica, but there is little doubt that some of the drugs which are supplied by the United States could be cultivated successfully in Canada. Another British country which has given good promise as a source of vegetab e drugs is Kenya, and it is understood that official encouragement will continue to begiven to experimentalstations in this colony. 